\title{
Hepatitis B Vaccination Strategy in HIV-infected Children
}

\author{
*Pooja Dewan and Piyush Gupta \\ From the Department of Pediatrics, University College of Medical Sciences and Guru Teg Bahadur Hospital, Delhi, India. \\ *poojadewan@hotmail.com
}

$\mathrm{H}$ epatitis B virus (HBV) and human immunodeficiency virus (HIV) share common risk factors and modes of transmission [1]. Co-infection with HBV and HIV can increase the risk of dying by upto 8 times [2]. HIV-infected children are also particularly vulnerable to reactivation of occult hepatitis-B infection, progression of HBV infection to chronicity, and lower rates of loss of serum $\mathrm{HBe}$ antigen following infection [3]. It is therefore important to prevent hepatitis B virus infection in HIVinfected children.

Following Hepatitis B vaccination, antibody to hepatitis-B surface antigen (anti-HBs) levels $\geq 10 \mathrm{mIU} /$ $\mathrm{mL}$ (measured by ELISA) is indicative of protective response. However, vaccine response to standard hepatitis-B vaccination is often blunted in HIV-infected children due to depletion of CD4+ T-cells, and altered distribution of T-cell and B-cell subsets. A decline in the total memory $\mathrm{B}$ cells (CD27+) and expansion of immature $\mathrm{B}$ cells $(\mathrm{CD} 10+)$ makes this population susceptible to a high rate of reinfection and waning vaccination-induced immunity [4]. The response rates to the 'classic' hepatitis-B vaccination schedule $(10 \mu \mathrm{g}$ at months 0-1-6) are much lower in children living with HIV compared to HIV non-infected children [5-9].

To achieve higher seroprotection rates, various vaccination strategies have been tried in these children, including the use of double-dose hepatitis-B vaccine $[10,11]$, additional doses of vaccination [10], intradermal route of vaccination [12], varying vaccination schedules (0-1-6 months, 0-1-2 months, 0-1-12 months, etc.), and the use of combination vaccines [11]. A meta-analysis by $\mathrm{Ni}$, et al. [13] recommends the use of increased dose of hepatitis-B vaccine for achieving adequate seroconversion after primary immunization in HIVinfected individuals.

These studies of hepatitis B vaccination in HIVinfected children are difficult to compare because of varied study designs and heterogeneous populations, disease and treatment status of subjects (Table I) [512,14]. There is no consensus, yet, regarding the best hepatitis-B vaccine schedule for primary immunization in HIV-infected children. Table II summarizes the recommendations on hepatitis B vaccination in HIVinfected children as advocated by various scientific bodies [15-18].

Factors shown to be associated with improved response to hepatitis-B vaccination include higher CD4 counts, undetectable HIV-1 viral load, younger age, increased dose and number of vaccines, and receipt of anti-retroviral therapy (ART) [19]. The use of ART is instrumental in viral suppression and restoration of immune functions, especially if initiated early in life. In several developing countries, HIV-infected children may not have access to ART until the CD4+ counts fall below the cut-offs of severe immunodeficiency, or until they get categorized as Stage 3 or 4 based on WHO Clinical staging of HIV-infection. The study by Siddiqui, et al. [14], published in the current issue of Indian Pediatrics, seems particularly relevant in a time of introduction of universal ART for HIV-infected children in India by National AIDS Control Organization (NACO) irrespective of their clinical or immunological staging. In this study, only a quarter of children (13/55) were receiving ART, which could explain the low rate of seroprotection. The study by Bunupurudah, et al. [12] was able to achieve $92.3 \%$ seroprotection in children (about $90 \%$ of who were receiving ART) with recombinant hepatitis-B vaccine in a standard dose (10 $\mu \mathrm{g}$ ) administered in a three-dose schedule. About $50 \%$ of these Thai children were able to mount a good seroprotection response (anti-HBs titers $>100 \mathrm{mIU} / \mathrm{mL}$ ). Siddiqui and colleagues [14] did not compare the proportion of good responders and the long-term immunity against hepatitis-B between the two groups. The study also has a major drawback in terms of a small sample size. No recommendation is possible based on the results of this study, though, it does add to the available scant data. 
EDITORIAL

TABLE I IMMUNOGENICITY OF HEPATITIS B VACCINE IN HIV-INFECTED CHILDREN

\begin{tabular}{|c|c|c|c|c|}
\hline $\begin{array}{l}\text { Study Group } \\
\text { (Year) }\end{array}$ & Dose and route & $\begin{array}{l}\text { Number of doses } \\
\text { (schedule) }\end{array}$ & Proportion on $A R T$ & Seroconversion \\
\hline $\begin{array}{l}\text { Siddiqui, et al. } \\
\text { (2017) [14] }\end{array}$ & $\begin{array}{l}10 \mu \mathrm{g} \mathrm{IM} \\
\text { vs } 20 \mu \mathrm{g} \mathrm{IM}\end{array}$ & $3(0-1-6 \mathrm{mo})$ & $\begin{array}{l}25 \% \text { in } 10 \mu \mathrm{g} \text { IM group } \\
v s 22.2 \% \text { in } 20 \mu \mathrm{g} \text { IM group }\end{array}$ & $\begin{array}{l}60.8 \% \text { in } 10 \mu \mathrm{g} \text { IM group } \\
v s 74 \% \text { in } 20 \mu \mathrm{g} \text { IM group }\end{array}$ \\
\hline $\begin{array}{l}\text { Bose, } \text { et al. } \\
(2016)[10]\end{array}$ & $20 \mu \mathrm{g} \mathrm{IM}$ & $4(0-1-2-6 \mathrm{mo})$ & $81.8 \%$ & $94 \%$ \\
\hline $\begin{array}{l}\text { Bunupurudah, } \\
\text { et al. (2011) [12] }\end{array}$ & $\begin{array}{l}10 \mu \mathrm{g} \text { IM } \\
v s 2 \mu \mathrm{g} \text { ID }\end{array}$ & $3(0-2-6 \mathrm{mo})$ & $\begin{array}{l}91.3 \% \text { on ART } \\
\text { IM: } 87.2 \% \\
\text { ID: } 95.1 \%\end{array}$ & $\begin{array}{l}90.2 \% \text { in ID } v s .92 .3 \% \text { in IM; } \\
56.1 \% \text { had good response (Anti } \\
\text { HBs }>100 \mathrm{mIU} / \mathrm{mL} \text { ) to Hepatitis } \\
\text { B vaccination in ID group } \\
\text { compared to } 82.1 \% \text { in IM group } \\
(P=0.01)\end{array}$ \\
\hline $\begin{array}{l}\text { Flynn, et al. } \\
\text { (2011) [11] }\end{array}$ & $\begin{array}{l}20 \mu \mathrm{g} \text { IM } v s 40 \mu \mathrm{g} \mathrm{IM} \\
v s \text { Twinrix }(20 \mu \mathrm{g} \mathrm{HBs} \\
\text { antigen } \& 720 \mathrm{ELU} \\
\text { HAV antigen })\end{array}$ & $3(0-1-6 \mathrm{mo})$ & $\begin{array}{l}20 \mu \mathrm{g} \text { IM: } 42 \% \\
40 \mu \mathrm{g} \text { IM: } 40 \% \\
\text { Twinrix: } 49 \%\end{array}$ & $\begin{array}{l}60 \% \text { in the } 20 \mu \mathrm{g} \text { IM group } v s \\
73.2 \% \text { in } 4073.2 \% \text { vs } 75.45 \% \\
\text { in Twinrix group }\end{array}$ \\
\hline $\begin{array}{l}\text { Pippi, et al. } \\
(2008)[9]\end{array}$ & $5 \mu \mathrm{g} \mathrm{IM}$ & $3(0-1-6 \mathrm{mo})$ & $52.8 \%$ & $\begin{array}{l}59.5 \%(70.8 \% \text { in ART } v s \\
44.4 \% \text { in non-ART })\end{array}$ \\
\hline $\begin{array}{l}\text { Thaithumyanon, } \\
\text { et al. (2002) [6] }\end{array}$ & $10 \mu \mathrm{g} \mathrm{IM}$ & $3(0-1-6 \mathrm{mo})$ & - & $71.4 \%$ \\
\hline $\begin{array}{l}\text { Rutstein, et al. } \\
\text { (1994) [7] }\end{array}$ & $10 \mu \mathrm{g}$ IM & $3(0-1-6 \mathrm{mo})$ & - & $35 \%$ \\
\hline $\begin{array}{l}\text { Diamant, et al. } \\
\text { (1993) [8] }\end{array}$ & $10 \mu \mathrm{g}$ IM & $3(0-1-6 \mathrm{mo})$ & $8 \%$ & $25 \%$ \\
\hline $\begin{array}{l}\text { Zuin, et al. } \\
\text { (1992) [5] }\end{array}$ & $10 \mu \mathrm{g} \mathrm{IM}$ & $3(0-1-6 \mathrm{mo})$ & - & $78 \%$ \\
\hline
\end{tabular}

ART: anti-retroviral therapy, ELU: ELISA units, HAV: Hepatitis A virus, ID: intradermal route, IM: intramuscular route.

TABLE II RECOMMENDATIONS OF HEPATITIS B VACCINATION IN HIV-INFECTED CHILDREN

\begin{tabular}{lll}
\hline Scientific Body & Dose of Hepatitis B vaccine & Schedule \\
\hline $\begin{array}{l}\text { Centers For Disease Control and } \\
\text { Prevention (CDC) [15] }\end{array}$ & Double dose $20 \mu \mathrm{g}$ & Three doses (0, 1-2, 4-6 months), IM \\
National Institute of Health (NIH) [16] & Standard dose $10 \mu \mathrm{g}$ & Three doses (0, 1-2 months, 6-18 months), IM \\
Children's HIV Association (CHIVA) [17] & Double dose $20 \mu \mathrm{g}$ & Three doses (0, 1-2 and 12 months), IM \\
Indian Academy of Pediatrics (IAP) [18] & Double dose $20 \mu \mathrm{g}$ & $\begin{array}{l}\text { Symptomatic HIV: Four doses } \\
(0,1,2,6 \text { months), IM }\end{array}$ \\
& & $\begin{array}{l}\text { Asymptomatic HIV: Three doses } \\
(0-1-6 \text { months), IM }\end{array}$ \\
\hline
\end{tabular}

IM: intramuscular route.

There is a need for studies evaluating immune response to hepatitis B vaccine in HIV-infected children receiving ART (as per current guidelines) to establish optimal vaccination schedule. It may be relevant to explore if the schedule needs to be tailored to suit different categories based on immune status measured by CD4 counts.

Funding: None; Competing interest: None stated.

\section{REFERENCES}

1. Inoue T, Tanaka Y. Hepatitis B virus and its sexually transmitted infection - an update. Microb Cell. 2016; 3:420-37.

2. Thio CL, Seaberg EC, Skolasky R Jr, Phair J, Visscher B, Muñoz A, et al; Multicenter AIDS Cohort Study. HIV-1, hepatitis B virus, and risk of liver-related mortality in the Multicenter Cohort Study (MACS). Lancet. 2002;360:1921-6. 
3. Rajbhandari R, Jun T, Khalili H, Chung RT, Ananthakrishnan AN. HBV/HIV coinfection is associated with poorer outcomes in hospitalized patients with $\mathrm{HBV}$ or HIV. J Viral Hepat. 2016;23:820-9.

4. Appay V, Almeida JR, Sauce D, Autran B, Papagno L. Accelerated immune senescence and HIV-1 infection. Exp Gerontol. 2007;42:432-7.

5. Zuin G, Principi N, Tornaghi R, Paccagnini S, Re M, Massironi E, et al. Impaired response to hepatitis B vaccine in HIV infected children. Vaccine. 1992;10:857-60.

6. Thaithumyanon P, Punnahitananda S, Praisuwanna P, Thisyakorn U, Ruxrungtham K. Antibody response to hepatitis B immunization in infants born to HIV-infected mothers. J Med Assoc Thai. 2002;85:277-82.

7. Rutstein RM, Rudy B, Codispoti C, Watson B. Response to hepatitis B immunization by infants exposed to HIV. AIDS. 1994;8:1281-4.

8. Diamant EP, Schetchter C, Hodes DS, Peters VB. Immunogenicity of hepatitis $B$ vaccine in human immunodeficiency virus-infected children. Pediatr Infect Dis J. 1993;12:877-8.

9. Pippi F, Bracciale L, Stolzuoli L, Giaccherini R, Montomoli E, Gentile C, et al. Serological response to hepatitis B virusvaccine in HIV-infected children in Tanzania. HIV Med. 2008;9:519-25.

10. Bose D, Chandra J, Dutta R, Jais M, Ray S, Gupta RA, et al. Immune response to double dose hepatitis-B vaccine using four dose schedule in HIV infected children. Indian J Pediatr. 2016;83:772-6.

11. Flynn PM, Cunningham CK, Rudy B, Wilson CM, Kapogiannis B, Worrel C, et al. Hepatitis B vaccination in HIV-infected youth: A randomized trial of three regimens. J Acquir Immune Defic Syndr. 2011;54:325-32.

12. Bunupuradah T, Ananworanich J, Pancharoen C, Petoumenos K, Prasitsuebsai W, Wongngam W, et al. Randomized study of intradermal compared to intramuscular hepatitis vaccination in HIV-infected children without severe immunosuppression. Vaccine. 2011;29:2962-7.

13. Ni JD, Xiong YZ, Wang XJ, Xiu LC. Does increased hepatitis $\mathrm{B}$ vaccination dose lead to a better immune response in HIV-infected patients than standard dose vaccination: A meta-analysis? Int J STD AIDS. 2013;24:117-22.

14. Siddiqui SA, Maurya M, Singh DK, Srivastava A, Rai R. Double dose versus standard dose hepatitis B vaccine in HIV-infected children: A randomized controlled trial. Indian Pediatr. 2017;54:1017-20.

15. Mast EE, Margolis HS, Fiore AE, Brink EW, Goldstein ST, Wang SA, et al; Advisory Committee on Immunization Practices (ACIP). A comprehensive immunization strategy to eliminate transmission of hepatitis B virus infection in the United States: recommendations of the Advisory Committee on Immunization Practices (ACIP) part 1: immunization of infants, children, and adolescents. MMWR Recomm Rep. 2005;54:1-31.

16. AIDSinfo. Guidelines for prevention and treatment of opportunistic infections in HIV-infected adults and adolescents. April 16, 2015. Available from: https:// aidsinfo.nih.gov/guidelines/html/4/adultand-adolescentoiprevention-and-treatment-guidelines/344/hbv. Accessed September 01, 2017.

17. Vaccination of HIV infected children (UK schedule, 2015). Available from: http://www.chiva.org.uk/files/3614/4587/ 9041/CHIVA_Vaccination_of_HIV_infected_ children_2015.pdf. Accessed August 20, 2017.

18. Indian Academy of Pediatrics. Guidebook on Immunization 2013-14. Available from: http:// www.iapindia.org/files/IAP\%20Guidelines/ IAP\%20Guidebook\%20on\%20Immunization\%20201314.pdf. Accessed August 20, 2017.

19. Catherine FX, Piroth L. Hepatitis B virus vaccination in HIV-infected people: A review. Hum Vaccin Immunother. 2017;13:1-10. 


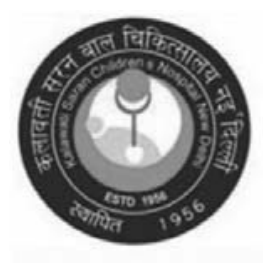

\title{
KSCH CME in Pediatrics-2018
}

\author{
$10^{\text {th }}$ and $11^{\text {th }}$ February 2018
}

Venue: Swarna Jayanti Auditorium, Shaheed Bhagat Singh Marg, Lady Hardinge Medical college, New Delhi, india 110001

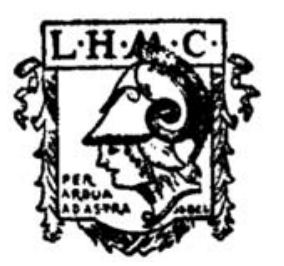

Department of Pediatrics, Kalawati Saran Children's Hospital, Lady Hardinge Medical College, New Delhi, and KSCH Doctors' Forum cordially invite Postgraduates, Practicing doctors and Paediatricians to its Annual academic feast "KSCH CME" on $10^{\text {th }} \& 11^{\text {th }}$ February 2018. KSCH CME has topics of day to day interest delivered by Stalwarts of Pediatrics who are working or have worked in Mecca of Pediatrics Kalawati Saran Children's Hospital, New Delhi.

\section{Scientific Program Highlights}

- Pediatric hypertension: guideline update

- Obesity and Dyslipidemia in children

- Approach to refractory rickets

- Guillain Barre syndrome: What's new

- Difficult to treat asthma/asthma mimicker

- UTI management and prophylaxis

- Approach to neonate with hydrops

- Recent advances in RDS

- Management of septic shock

- Interpretation of Pediatric Chest X-ray

- Panel discussion- Newer vaccines

- Feeding recommendation in HIV exposed infants
- Non invasive ventilation in PICU

- Probiotics in acute diarrhea

- Approach to child with sexual abuse

- Screening for autism: red flag signs

- Rehabilitation of patients with cerebral palsy

- Nutritional anaemias: beyond iron therapy

- Case vignettes: Scrub typhus/ Novel influenza

- Management of common outpatient surgical cases

- Panel discussion: Rational antimicrobial policy

- Quiz with attractive prizes

\section{Patrons:}

Dr Rajiv Garg, Director, Lady Hardinge Medical College \& Associated hospitals, New Delhi Dr. Jagdish Chandra, Director Professor, Kalawati Saran Children Hospital, New Delhi

\section{Organizing Chairperson:}

Dr. Virendra Kumar, Head Department of Pediatrics, Lady Hardinge Medical College \& Associated hospitals, New Delhi.

Registration Details: Until 31 ${ }^{\text {st }}$ December: Rs 1500/-, $1^{\text {st }}$ January 2018 onwards and Spot: ₹ 2000

- Online Registration via Card/Net-banking http://www.meraevents.com/event/ksch-cme-in-pediatrics2018 (Event ID: 135406)

- Send Demand Draft/Cheque in favour of “KSCH Doctors Forum” payable at Delhi, to Head, Department of Pediatrics, Room Number 118, Kalawati Saran Children Hospital, Bangla Sahib Marg, New Delhi, 110001. Phone/Fax 011-23365792, Email: kschcme2018@gmail.com

For further information, and assistance for local transport and accommodation please contact:

Organizing Secretary: Dr Praveen Kumar; Dir. Professor of Pediatrics, LHMC, New Delhi; Mobile: 9868579672; Email: pkpaed@gmail.com

Co-Organizing Secretary: Dr Ankita Goel Sharma, Assistant Professor of Pediatrics, LHMC, New Delhi; Mobile: 9711278490; Email: ankitagoel.85@gmail.com 